2017-07-02

\title{
German childhood services emphasise social pedagogy
}

Hohmann, Ulrike

http://hdl.handle.net/10026.1/12503

10.12968/eyed.2017.19.3.14

Early Years Educator

Mark Allen Group

All content in PEARL is protected by copyright law. Author manuscripts are made available in accordance with publisher policies. Please cite only the published version using the details provided on the item record or document. In the absence of an open licence (e.g. Creative Commons), permissions for further reuse of content should be sought from the publisher or author. 


\section{Early Childhood Education and Care in Germany}

Ulrike Hohmann

Early Childhood Education and Care (ECEC) services are well established in Germany, especially for children from the age of three to when they start school. Legislation covering all the 16 countries of the Federal Republic of Germany sets out the general duty of the state to support parents in their task to raise and educate children and the entitlement of all children to ECEC services from their first birthday. Detailed regulation of services, structures and financing of settings and the training of the workforce are the responsibility of the individual countries and/or municipalities. This short article can offers only a general overview, but details at local level may show further variations.

\section{What are the different services and which children do they cater for e.g. childcare for 0-2, preschool for 3-6}

There are full-time and part-time place for children from birth to when they start school and services for children before and after school. Krippe caters for children from birth to the third birthday, Kindergarten offers part-time places for 3-6 year old children, usually without lunch and in age-mixed groups, Kindertagesheim offer full-time services to children from birth to 14 year olds, but divided in groups of birth to 2 year olds, 3-6 year olds and school aged children, though other age combinations are possible. Hort offers out-of-school care. Names, structures and coverage show some variation between the 16 countries of federal state of Germany. There are also family day care providers, Tagesmutter or Tagesvater [day mother or day father], usually looking after birth to three year old children.

In 2016 about a third of children from birth to two attended some form of ECEC settings and 90 per cent of 3-5 year olds. Older children are more likely to attend, for example, 98 percent of 5 year olds take up a place (Statistisches Bundesamt 2017).

\section{School starting age}

German children start school when they are 6 years old. Depending on their mental and physical development they may start a year earlier or a year later. There are some variations between the 16 countries of Germany.

\section{Qualification requirements for staff}

Being responsible for one group of children (or room) within a setting requires the qualification as Staatlich Anerkannte Erzieherin [state approved child-raiser] (short: Erzieherin). The training lasts four years including extensive placements. This qualification is equivalent to a Bachelor degree. Further support staff have to be trained as Staatlich Anerkannte Kinderpflegerin [state approved child carer] (short: Kinderpflegerin) or 
equivalent, similar to NVQ Level 3. The training lasts three years, including placements. Managing a setting requires the qualification of Social Pedagogue or Early Childhood Pedagogue, a qualification awarded by universities, or extended experience as Erzieherin and some CPD.

\section{Professional development requirements}

Settings are required to ensure CPD of their staff and staff have the right to take some paid leave to do so. CPD takes place in-house and may be offered by the youth office of the country or the service provider.

\section{Who works in ECEC}

Most staff working in ECEC are women There are only five per cent of men working in this sector and they are often managing settings. The average age of women in ECEC is 41 years in contrast to that of men with 34 years. Erzieherinnen are the largest professional group working in ECEC settings with 67 per cent of pedagogical, leading and administrative staff. Eleven per cent of the staff hold the qualification Kinderpflegerin. The income of all of these occupational groups is substantially lower than that of a primary school teacher.

\section{Pedagogy and learning environments (and how these all compare and contrast with the UK)}

The ethos of German ECEC services emphasises social pedagogy approaches that embeds working with people within social space created by relationships. Children are seen as strong persons with a right to a good life in the here and now. They are important partners in the construction of Lebenswelten [life words], in families, with friends and in their neighbourhoods. The ECEC setting is one of the important spaces in which children develop relationships beyond their own family.

The work with children is practical and relationships are built with the help of art and music and through everyday life activities in the community. One of the most important resources of a practitioner is her attitude and her concept of childhood and young people, resulting in respect and acknowledgement of children's rights and trust. The work with groups of children and supporting positive relationships among children is the task of the practitioner. One sign of successful work is the dispensability of impact of the pedagogue for children's engagement with the life world. The personality of the practitioner is her 'tool', and she uses her personal life experience to enhance her work as long as it is for the benefit of the children. It requires theoretical understanding, self-knowledge and constant reflection. They have been trained to use art and music techniques with children. Her work is firmly embedded in the community and does not lose sight of social dimensions (Eichsteller and Holthoff 2011). 
This social pedagogical, inclusive approach also informs the structures of settings. Building relationships takes time and requires stability. For example, most children entering kindergarten at the age of 3 remain in the same group of children and with the same members of staff (one Erzieherin and one Kinderpflegerin per group) until they leave to start school. A place in a setting is a place for one child and cannot by shared between two or more children. There are 9-12 places in a group for children younger than three and up to 25 places in groups for children 3-6 years old. Children are encouraged to be considerate towards their younger peers. Some milestones are achieved with ease, since younger children admire their older peers and want to be just like them. A staff child ratio like in England, setting out how many adults are required to be present for a set number of children at any one time, does not exist.

\section{Any pressures the system is under, the challenges faced}

There are new demands on the work with children, too. The first set of findings of Programme of International Student Assessment (PISA) shocked Germany with unexpected results in the middle of the ranking table (OECD 2001). One answer was the demand to emphasise education in early years and each of the German countries developed a framework or guidance for the work in ECEC settings. They are required to improve children's language competencies, especially in those children with a migration background and helping children to become ready for school education.

Since 2013 children in Germany have the legal entitlement to a place once they are one year old. The entitlement includes access to a part-time place in any of the ECEC settings and parents have to pay fees. Most ECEC settings are provided by non-profit making NGOs (nongovernmental organisation), connected to the churches or to Trade Union welfare organisations. Places are financed by the country, the municipality and fees from parents.

The entitlement reflects a number of intentions. One is to improve the low birth rate in Germany. Parents should become more flexibility in combining paid work and family life. Children should have access to early education. Education and care for all young children in Germany aids inclusion of people from all ethnic groups, promotes equality and prevents discrimination.

There are many communities who struggle to expand places and to train an increasing number of staff. Working conditions are often stressful and practitioners may feel out of their comfort zone. For example, the tradition training of an Erzieherin focus on 3-6 year old children. Now they are expected to cater for younger children, including their physical needs. Extending the age range in a group of children, some range now from 1-14 years of age demand new pedagogies. The issue of integration of children from different cultures and the responsibility to support children in learning German as second language is also new to many practitioners. Working with parents from a wide variety of backgrounds and perhaps with a different view of a good childhood demands also additional skills.

Whilst writing the Family Minister of the federal government announced additional funding, the equivalent to $f 2.1$ million to create up to 100,000 new places and, that is new, to improve quality in settings. 


\section{References}

Eichsteller, G. and Holthoff, S. (2011) Conceptual foundations of social pedagogy: A transnational prespective from Germany, C. Cameron and P. Moss (eds) Social Pedagogy and Working with Children and Young People London and Philadelphia: Jessica Kingsley Publishers.

Statistisches Bundesamt. (2017) Kinder in der Tagesbetreuung 2015/2016.

https://www.destatis.de/DE/ZahlenFakten/GesellschaftStaat/Soziales/Sozialleistungen/Kindertagesb etreuung/Tabellen/Tabellen KitabetreuungMerkmale.html: accessed: 04.04.2017

\section{Further reading}

Cameron, E. and Moss, P. (eds) (2011) Social Pedagogy and Working with Children and Young People, London and Philadelphia: Jessica Kingsley Publisher

Hohmann, U. (2015) 'Germany: parallel histories in ECEC', V. Campell-Barr and J. Georgeson (eds) International Perspectives on Early Years Workforce Development Northwich: Critical Publishing.

Oberhuemer, P., Schreyer, I. and Neuman, M. (2010) Professionals in Early Childhood Education and Care Systems: European Profiles and Perspectives. Opladen \& Farmington Hills: Barbara Budrich.

Rabe-Kleberg, U. (2009) 'Maternalism and Truncated Professionalism - Historical Perspectives on Kindergarten Teachers', K. Scheiwe and H. Willekens (eds) Child Care and Preschool Development in Europe: Institutional Perspectives Basingstoke: palgrave macmillan.

Rauschenbach, T. and Riedel, B. (2016) 'Germany's ECEC workforce: a difficult path to professionalisation', Early Child Development and Care, 186(1): 61-77. 